\title{
About Some Environmental Consequences of Kerch Strait Bridge Construction
}

\author{
Romashchenko Mykhailo Ivanovych, Yatsiuk Mykhailo Vasylovych, \\ Shevchuk Sergiy Anatoliyovych, Vyshnevskyi Viktor Ivanovych, Savchuk Dmytro Petrovych
}

Institute of Water Problems and Land Reclamation NAAS, Kyiv, Ukraine

Email address:

mi.romashchenko@gmail.com (M. I. Romashchenko), mv_yatsiuk@ukr.net (M. V. Yatsiuk), sergey_shevchuk_@ukr.net (S. A. Shevchuk)

\section{To cite this article:}

Romashchenko Mykhailo Ivanovych, Yatsiuk Mykhailo Vasylovych, Shevchuk Sergiy Anatoliyovych, Vyshnevskyi Viktor Ivanovych, Savchuk Dmytro Petrovych. About Some Environmental Consequences of Kerch Strait Bridge Construction. Hydrology.

Vol. 6, No. 1, 2018, pp. 1-9. doi: 10.11648/j.hyd.20180601.11

Received: November 29, 2017; Accepted: December 18, 2017; Published: January 16, 2018

\begin{abstract}
After the annexation of the Crimean peninsula by the Russian Federation, the construction of the Kerch bridge crossing, which has not been coordinated with Ukraine, has been started, which in the near future may lead to the destruction of the unique flora and fauna of the Black and Azov Seas. The results of the Kerch Strait Bridge construction consequences for the environment are presented. The main sources of data were the materials of remote sensing (RS), National Aeronautics and Space Administration (NASA), European Space Agency (ESA), US Geological Survey (USGS), literary sources, as well as the results of Tuzla Island survey carried out before the beginning of construction. The data regarding ecologic and hydrologic situation caused by the Kerch Strait Bridge construction were processed for the period between 2014 and 2017. An expert evaluation was conducted to determine the damage caused to Ukraine as a result of the construction of the Kerch Bridge, as well as the gathering of evidences upon violations of Ukrainian and international legislation for further consideration in international courts. The conclusion about significant changes in the water regime of the Kerch Strait and the entire Sea of Azov was made.
\end{abstract}

Keywords: Ukraine, Kerch Strait, Tuzla Island, Sea of Azov, Satellite Data, Ecosystem Hazards

\section{Introduction}

Kerch Strait is a natural formation that connects the Black and the Azov seas. Its length is equal to $43 \mathrm{~km}$ with the smallest width of $3.7 \mathrm{~km}$. The strait is relatively shallow; the deepest place from Azov Sea side has 10.5 meters depth and from the Black Sea side -18 meters.

A unique feature of the Strait is the location of Tuzla Island almost in the middle of it. The island stretches from northwest to southeast and has a length of about $6.5 \mathrm{~km}$.

The largest depths in the Kerch Strait is located near the Crimean peninsula. Here runs the Kerch-Yenikalskyi Shipping Canal, the navigability of which is supported by dredging.

The Kerch-Yenikalskyi Shipping Canal in the Kerch Strait links the Azov and the Black Seas. The ships traffic through the canal and in the Azov Sea is regulated by the United Nations Convention on the Law of the Sea (1982).
The depth of the strait between Tuzla Island and Taman peninsula is low and it is sufficient only for the passage of small ships.

Russia's unilateral actions regarding the construction of the Kerch Strait Bridge is considered as an offend against international laws and the sovereign rights and jurisdiction of Ukraine over enclosed waters, the territorial sea, the exclusive economic zone and the continental shelf in the Black and the Azov Seas.

According to the project, the height of the Kerch Strait Bridge in the place of shippings should be equal to $35 \mathrm{~m}$ with the depth of the fairway below it equal to $9 \mathrm{~m}$. This means that only ships with a height of no more than $33 \mathrm{~m}$ and a draft of up to $8 \mathrm{~m}$ will be able to get to the Ukrainian ports of the Sea of Azov. Through these restrictions Ukrainian ports in Mariupol, Berdiansk and Henichesk can lose significant amounts of revenue.

The bridge construction project has not undergone environmental impact assessment. Therefore, existing 
scenarios for the development of the ecological situation in the Kerch Strait are rather conditional. However, environmentalists have no doubt that this infrastructure project will disrupt the existing ecosystem, including the natural water exchange between the Azov and the Black seas, which will harm the flora and fauna primarily of the Azov Sea [1]. There is also the opinion that the construction and operation of the Kerch Strait Bridge will transform the Sea of Azov into the Black Sea Gulf. Winter conditions are the most worrying. The Sea of Azov freezes and cargo shipping is possible only after laying an icebreaker route. The bridge pillars will hold off a large array of ice. Its accumulation can block the passage of ships under the bridge.

\section{The History of the Issue}

On the first known maps of the Kerch Strait, composed by Venetian sailors at the end of the XIV century, Tuzla is shown as an island. The same thing is on the map of 1559. Interestingly enough, in the next three centuries, the situation remained unchanged - on the map of 1855 Tuzla is also shown as an island. Only in the late XIX century Tuzla was connected with the Taman peninsula. The formed spit was convenient to the island's population and therefore the tendency was to maintain it. However, the strong storm that occurred on November 29, 1925 finally eroded the spit, forming a duct with a width of several hundred meters (Figure 1). Over the next decades its width has reached $4 \mathrm{~km}$.

The possibility of a bridge construction over the Kerch Strait was considered during the Soviet Union time, but because of the complicated geological situation, in particular the danger of earthquakes, this idea was abandoned.

After the liberation of the Crimea from the German occupation, the Decree of the State Committee of Defence of the USSR No. 5027 dated January 25, 1944 set the task of constructing a secret object "K-2" - a railway bridge across the Kerch Strait in the shortest possible time. The operations started on April 24, 1944. It was a temporary one-track railway bridge with the scheme of $11527.1 \mathrm{~m}$ deck spans and two $55 \mathrm{~m}$ fairway arches with rotary farms [2].

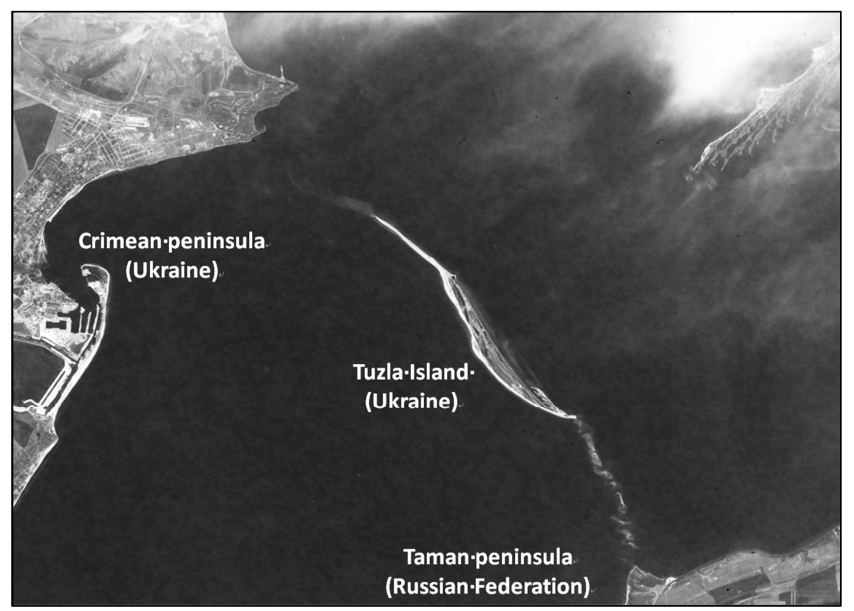

Figure 1. The Kerch Strait on satellite images on May 03, 1968 with the remains of the sand spit blurred by storm in 1925.
The winter of 1944-45 turned out to be cold, so there were powerful hollow-shaped ice fields in the Sea of Azov, which under the influence of a wind came in motion. At about four o'clock in the morning on February 18, 1945, under the pressure of a stormy wind and heavy ice, four spans of the bridge collapsed. In the afternoon, another ten fell. The bridge could not be reconstructed and was later dismantled.

The next large-scale construction in the Kerch Strait took place in the autumn of 2003. Without any warning Russia began dumping stone in the dam body shoreward Tuzla Island. It was stopped when the island was in about $100 \mathrm{~m}$.

After the annexation of Crimea in the spring of 2014 the Russian leadership has publicly voiced intent to build a bridge across the Kerch Strait which soon embodied in largescale construction. The chosen route passed through the Tuzla Island and the mentioned section of the dam that was built in 2003 (Figure 2).

\section{Highlights of the Issue}

The Kerch Strait has not only economic but also a significant ecological value. There is water exchange between the Black and the Azov Seas through the Strait. This is especially important for the Azov Sea, which is the smallest by volume and the most remote sea of the World ocean. The area of the sea is 38 thousand square $\mathrm{km}$ or 40 thousand square km taking into account the Gulf of Syvash. The maximum depth of the sea is only $13.5 \mathrm{~m}$, which is less than the maximum depth of the Dnieper reservoirs.

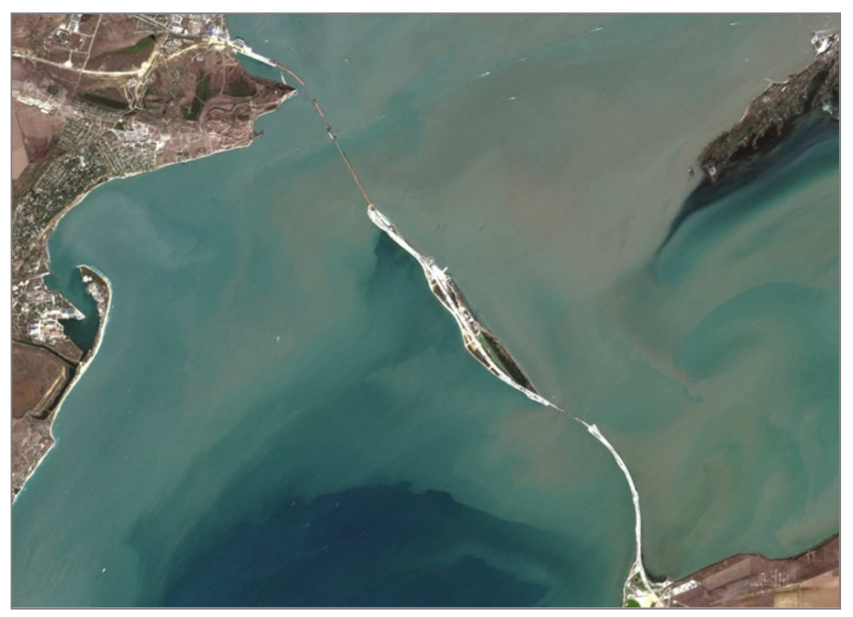

Figure 2. The Kerch Strait, Ukraine, Russia, satellite image in colors close to natural, Sentinel-2A, 2017. 10. 01., resolution $10 \mathrm{~m}$.

Inflow of a fairly large volume of fresh water (mainly the flow from the Don and Kuban rivers) causes the salinity of the Azov Sea to be significantly lower than in the Black Sea: $10-12 \%$ and $17-18 \%$ respectively. In fact, the salinity of the sea varies greatly in the aquatic area with its lowest values in the Taganrog Gulf in which the Kuban River runs into. The highest salinity, putting aside the Syvash, is near the Kerch Strait [3].

The small size of the sea affects the regime of its levels. They are the highest after the seasonal flood in Don and 
Kuban rivers (in June), the lowest - in October after the end of the summer-autumn low water in these rivers. The amplitude of the seasonal level fluctuations reaches $25 \mathrm{~cm}$. The sea's shallowness affects the existence of significant surge phenomena whose amplitude often exceeds $1 \mathrm{~m}$. It causes flooding of the lowlands or baring of the bank for several hundreds of meters.

The predominance of shallow areas in the Azov Sea leads to it's warming up in summer (sometimes the water temperature near the shore exceeds $30^{\circ} \mathrm{C}$ ). At the same time, in the winter, the sea freezes: in cold winters completely, in warm - partially (mostly in the gulfs).

Another feature of the Azov Sea is its high fish productivity which is significantly higher than in the Black Sea. The main industrial fish are gobies, Azov anchovy, mullet, so-iny mullet (pelingas). The sea is also inhabited by sturgeons which are now listed in the Red Book of Ukraine.

The transport value of the Sea of Azov is also significant. In particular, Ukrainian ports Mariupol and Berdiansk are situated on its shores. The first is one of the largest in Ukraine.

Construction of a transport passage across the Kerch Strait is carried out in complicated engineering and geological conditions due to the danger of seismic manifestations and ice processes. The bridge is located in the area of complex natural system under the conditions of sea surface currents development and water surge [4]. It is also worth to take into account that in the place where the bridge is constructing there are several tectonic faults and mud volcanoes. The bridge passage is expected through the seismically active zone - approximately 9 points on the Richter scale, which is a critical value for such structures [5].

These construction conditions constitute a high degree of the risk of negative consequences for the ecological state of the Kerch Strait and the Sea of Azov. The fact that such impact will exist can be proved at least by the study of Russian documents relating to the construction of an artificial spit between Tuzla Island and the Taman Peninsula. At one time, such documents were provided to the Ukrainian side when the construction of the dam was conducted in 2003.

Another witness of the negative effects of constructing the bridge is also evident in the actions of Russia on the legislative regulation of this issue. There is the Federal Law of the Russian Federation from July 13, 2015, No. 221-FZ "On the distinctions of the regulation of certain legal relations arising in connection with the construction, with the reconstruction of transport infrastructure facilities of federal and regional importance designed to provide transport links between the Taman and the Kerch peninsulas, and engineering infrastructure facilities of federal and regional importance on the Taman and the Kerch peninsulas and on introducing of amendments in certain legislative acts of the Russian Federation". The law reduced the period of environmental impact assessment as well as simplified the procedure for obtaining construction permits.

The State Duma, the lower house of the Russian Federation parliament, also introduced amendments to the laws on environmental impact assessment, on natural areas under special protection, the Water and Land Codes of the Russian Federation. Now, the soil remaining after dredging works can be dumped at any point of the Sea of Azov without ecological approval. Only 45 days is provided for the state environmental impact assessment. As a matter of fact, the new law allows not waiting for any examinations and permits to start construction work.

Ukrainian legislation is completely different. According to the Article 86 of the Water Code of Ukraine, operations related to the construction of hydraulic engineering structures, linear and hydrometrical structures, bed deepening for navigation purposes, mining of minerals (except for sand, pebbles and gravel in the beds of small and mountain rivers), clearing rivers beds, canals and bottom of reservoirs, laying cables, pipelines, other communications, as well as drilling and exploration works can be carried out on the lands of the water fund.

Places and the procedures for carrying out the mentioned works shall be determined in accordance with the projects approved by the oblast, Kyiv, Sevastopol city state administrations, the executive body of the Autonomous Republic of Crimea on environmental protection, the central executive authority, which implements the state water management policy (except the works on lands occupied by seas), and a central executive body that implements state policy in geological study and rational use of mineral resources. It means that the construction of transport crossing over the Kerch Strait made without compliance with the Water Code of Ukraine is a direct violation of current legislation of Ukraine.

In addition, the construction of the bridge directly across the Tuzla Island is an ecologically unacceptable solution. The bridge transition construction caused irreparable environmental damage to cape of Tuzla on the territory of which there are active geological survey works, and the island with the same name which turned into a huge parking lot and the warehouse for building materials. Builders have cut down part of forest plantations on the island. We can state that Tuzla, as a unique and important natural area for marine and migratory birds have ceased to exist.

As a result of construction, water exchange between the Black and the Azov seas has also significantly changed. Before the construction of an artificial spit, the sea currents uniformly flow around the Tuzla Island with low velocities, now the main flow of water with high velocity passes between the Tuzla Island and the Kerch peninsula (Figure 38 ). At the same time, the velocity of the flow in the narrow strait between Tuzla Island and the artificial dam that was built has also increased. Not surprisingly, there is an intensified erosion of the south-eastern part of the Tuzla Island, which is still not completely secured.

The deterioration of water exchange in the Kerch Strait significantly affects the temperature and ice conditions of the Strait directly and the Azov Sea in general. As a result, in summer the temperature of the water will increase, and in winter it will decrease. The latter will significantly 
deteriorate the ice regime - not only the period of ice formation, but its thickness will increase as well. It is important to notify, that the most affected area will be the Kerch Strait, which is almost completely blocked by a dam and a large number of bridge pillars before the completion of the construction. This is evidenced by available satellite images in winter 2017.

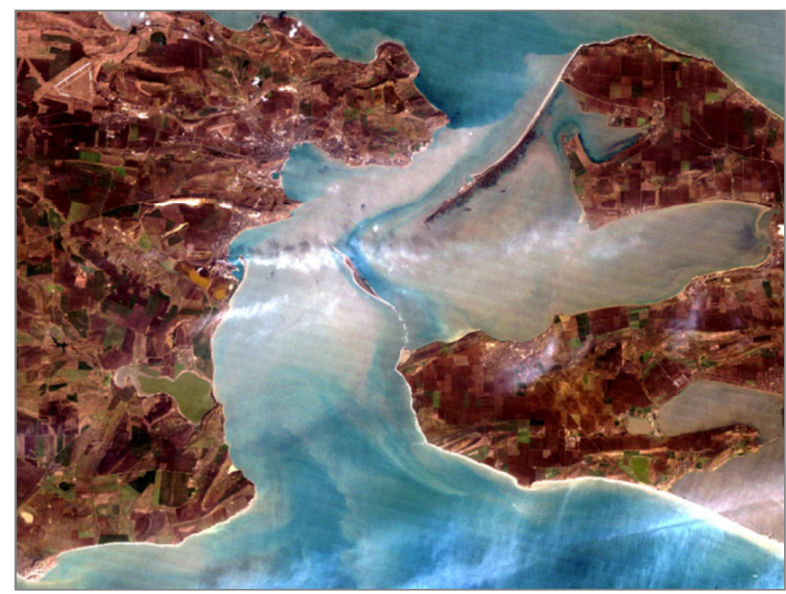

(a)

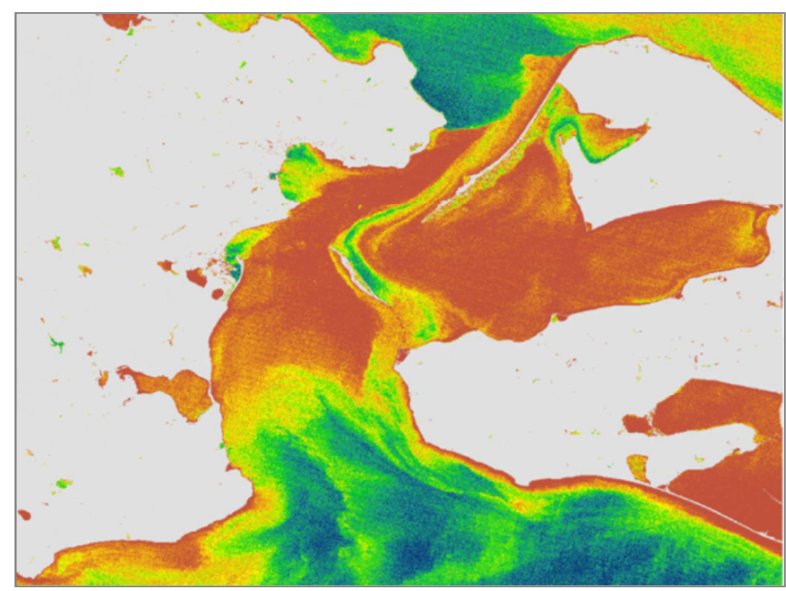

(b)

Figure 3. Satellite images of the Kerch Strait. Landsat 5 dated 17 Feb 1990.. $a$-false natural colours; $b$ - in turbidity values.

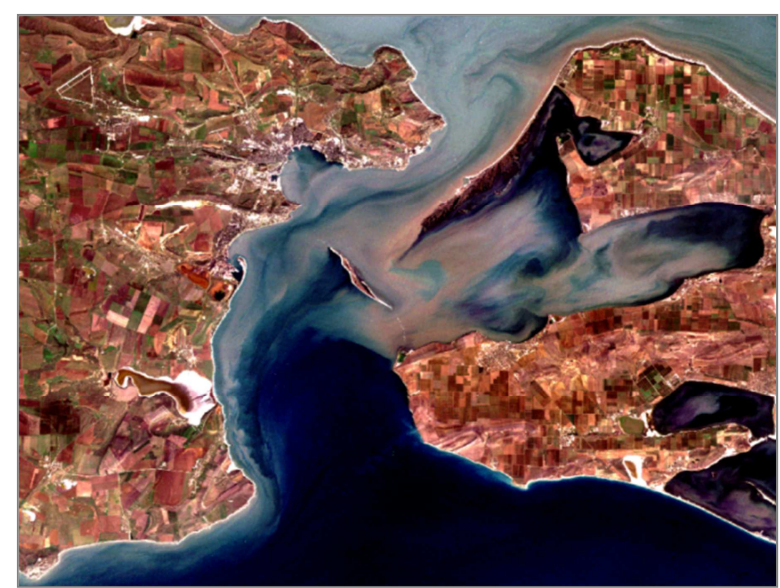

(a)

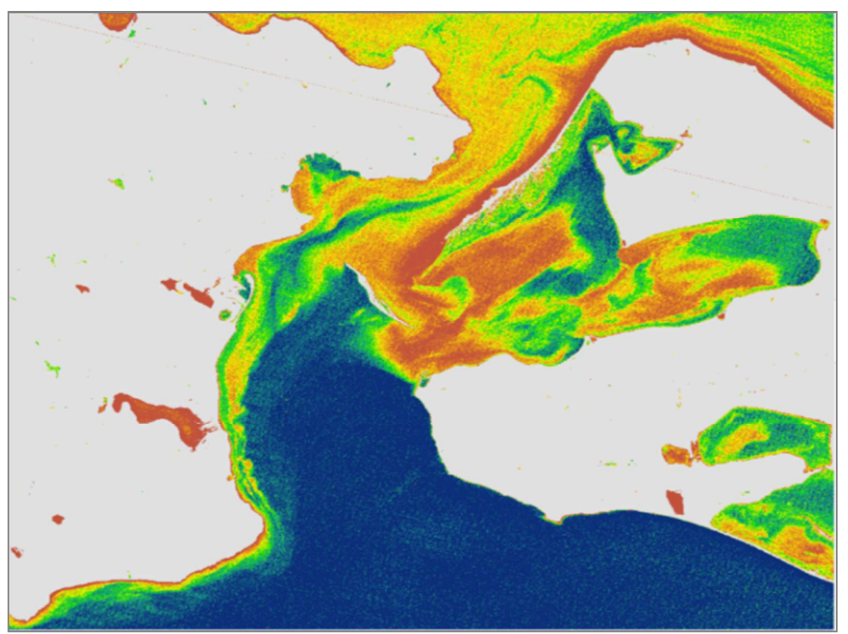

(b)

Figure 4. Satellite images of the Kerch Strait. Landsat 5 dated 10 Oct 1991.. $a$-false natural colours; $b$-in turbidity values.

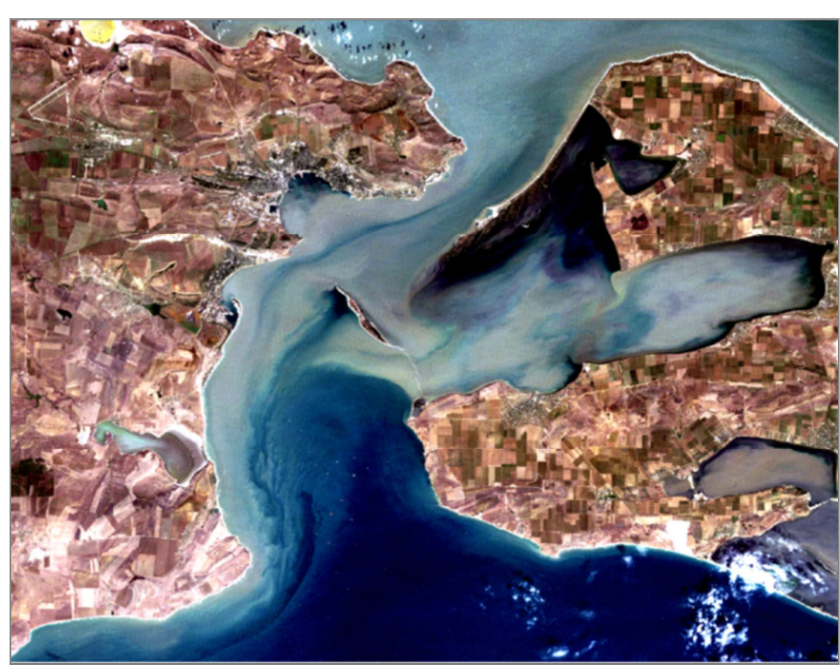

(a)

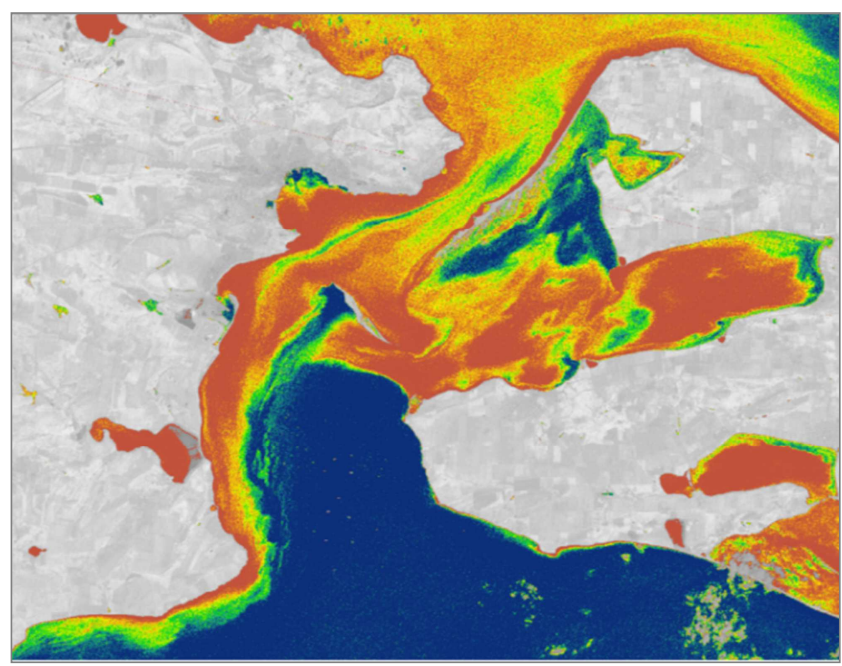

(b)

Figure 5. Satellite images of the Kerch Strait. Landsat 5 dated 19 Sep 2001.: $a$-false natural colors; $b$-in turbidity values. 


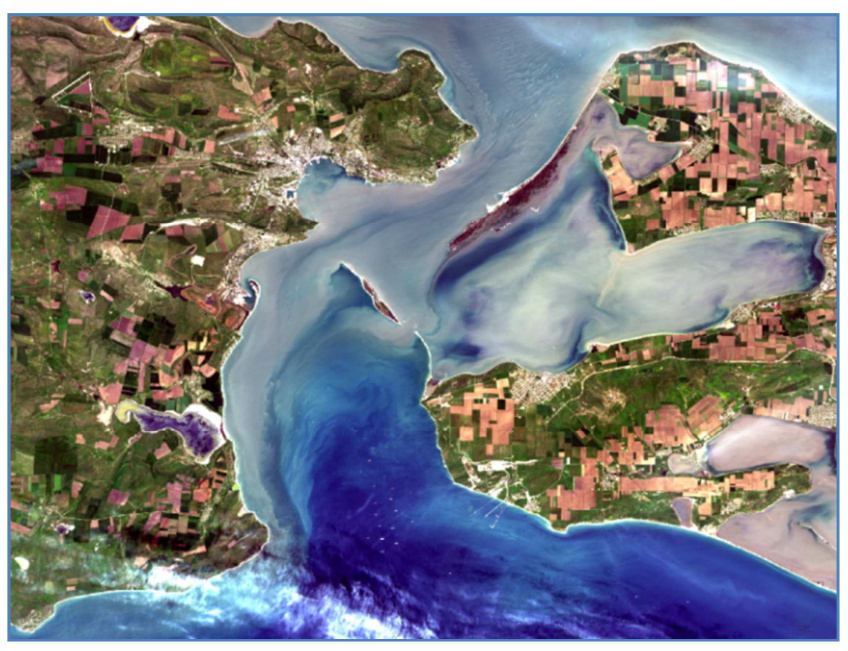

(a)

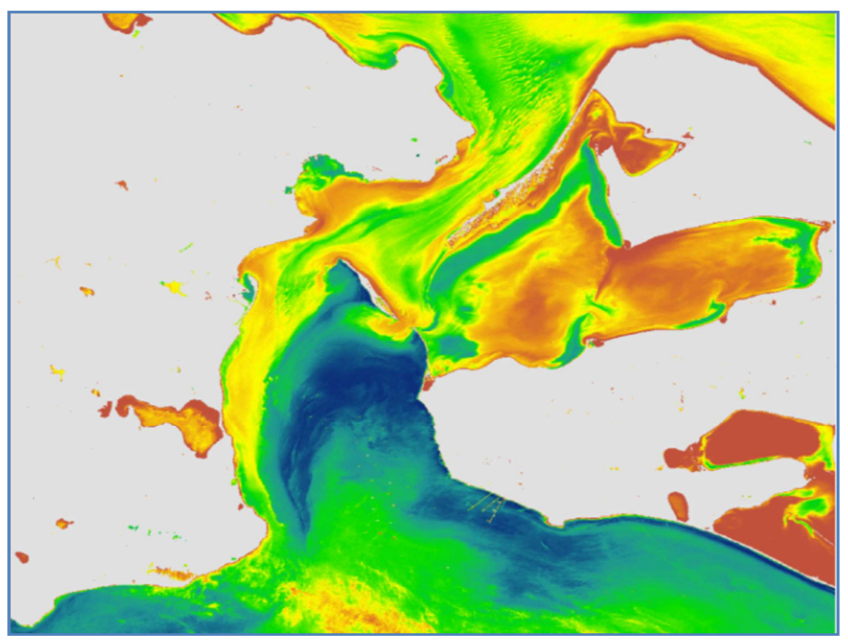

(b)

Figure 6. Satellite images of the Kerch Strait. Landsat 8 dated 21 May 2015. $a$-false natural colors, $b$ - in turbidity values.

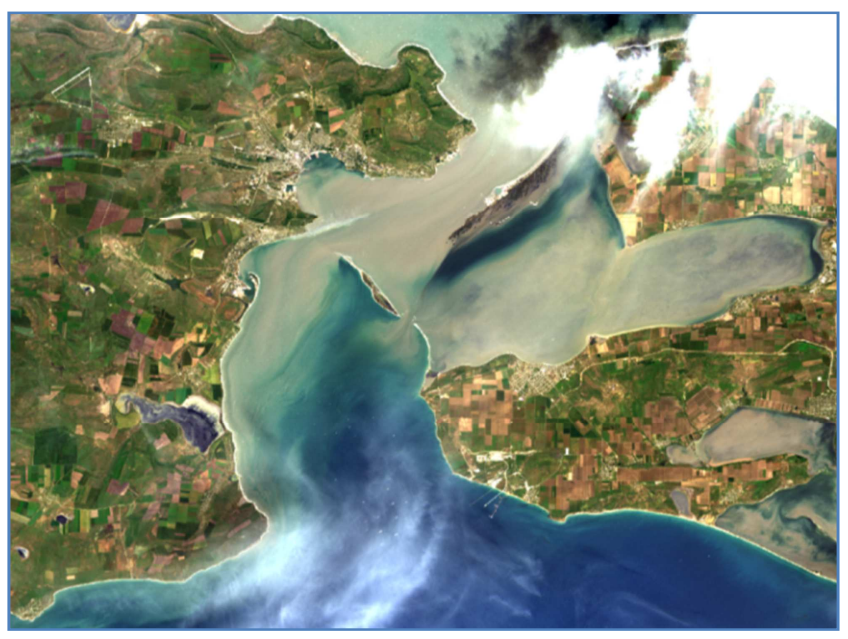

(a)

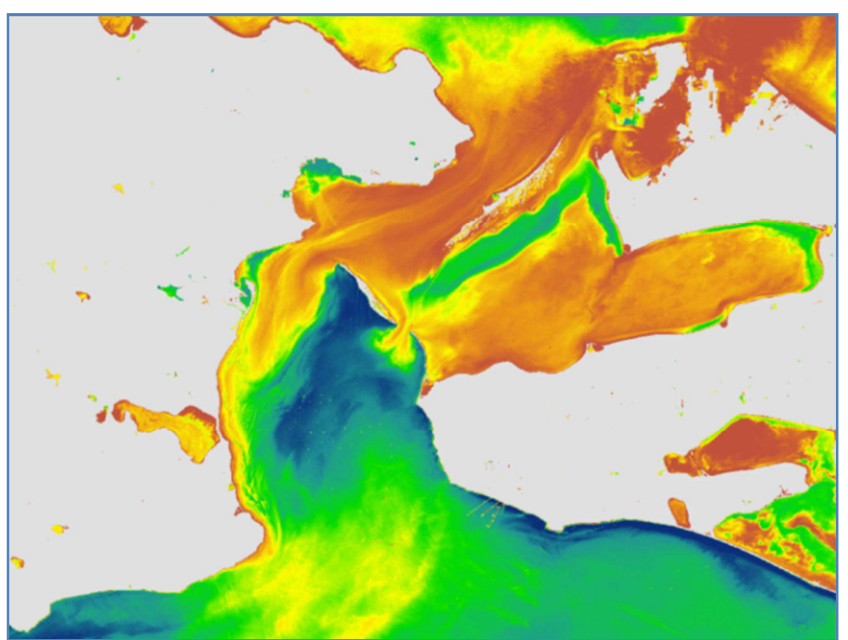

(b)

Figure 7. Satellite images of the Kerch Strait. Landsat 8 dated 06 Jun 2015. $a$-false natural colors, $b$ - in turbidity values.

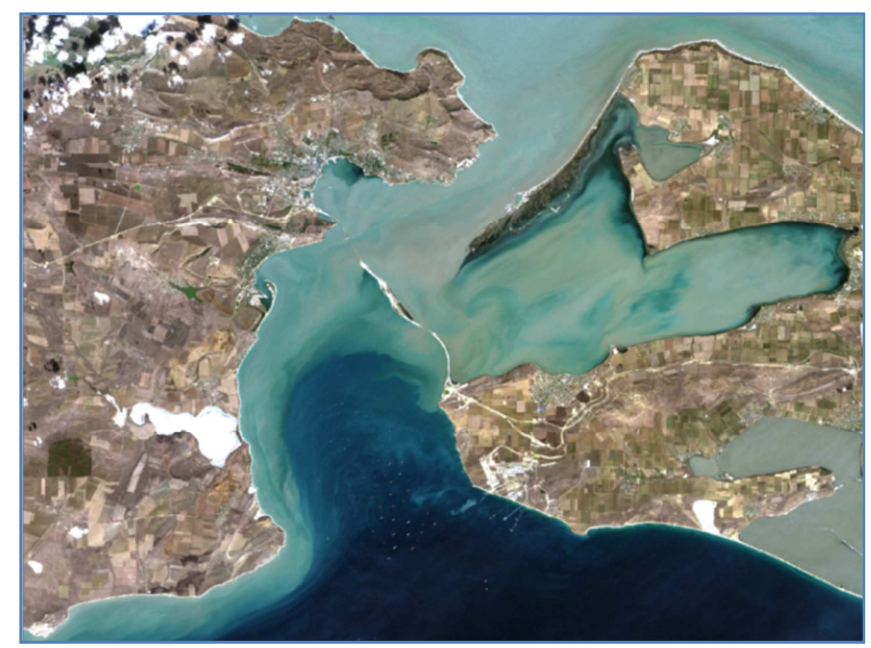

(a)

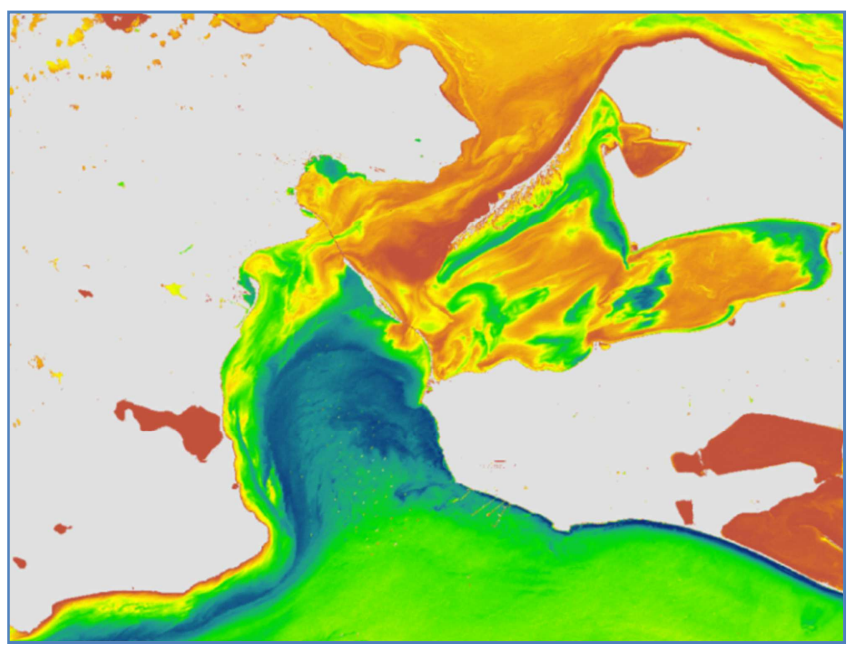

(b)

Figure 8. Satellite images of the Kerch Strait. Landsat 8 dated 01 Oct 2017: $a$-false natural colors, $b$ - in turbidity values.

Under the influence of the northern winds in the first ten 
days of February 2017, the withdrawal of ice from the Sea of Azov began, and during the next few days almost all of the northern part of the Kerch Strait was covered with ice (Figure 9, 10).

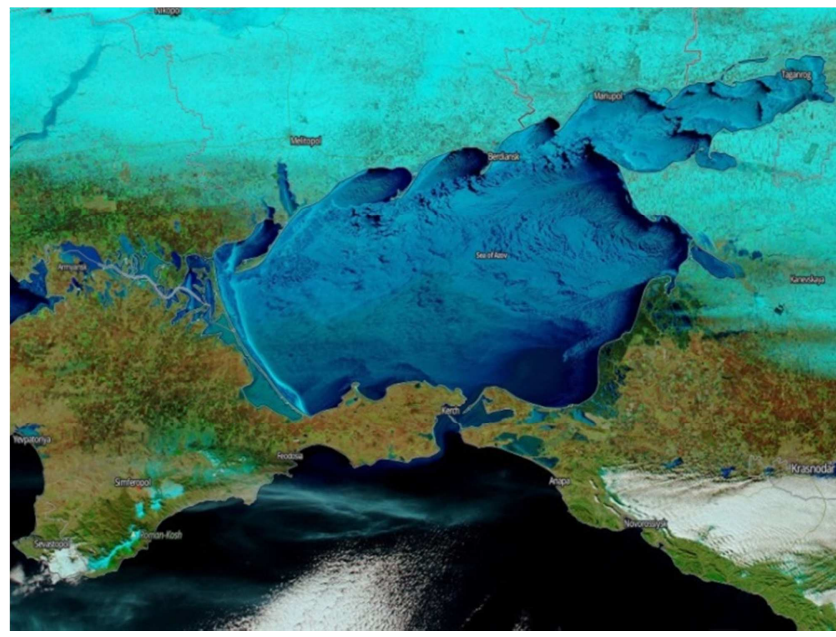

09 Feb 2017

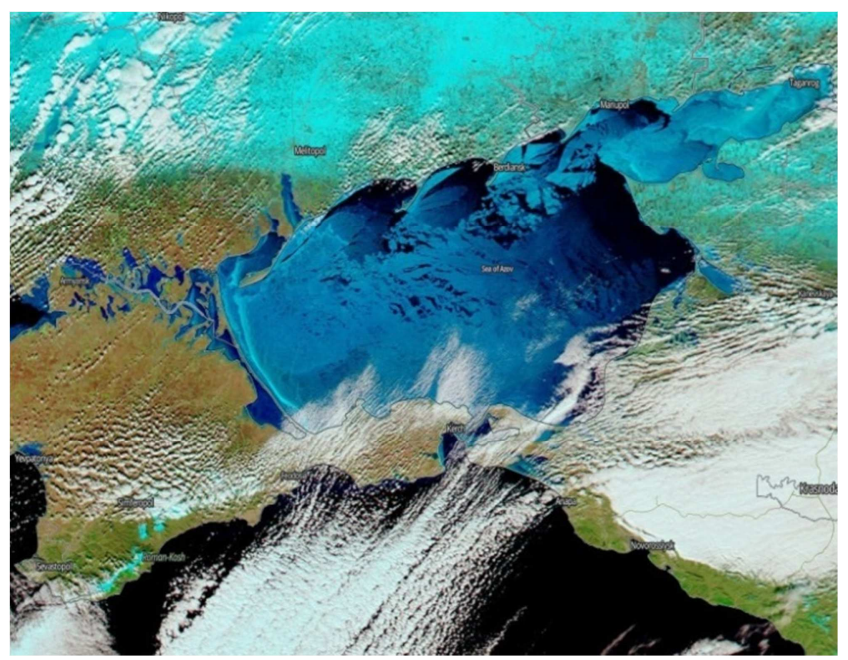

12 Feb 2017

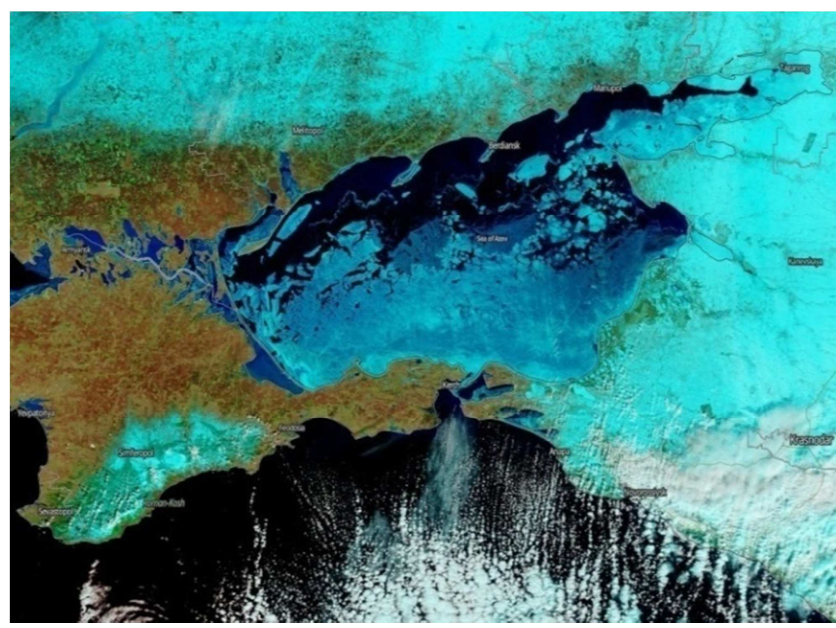

16 Feb 2017

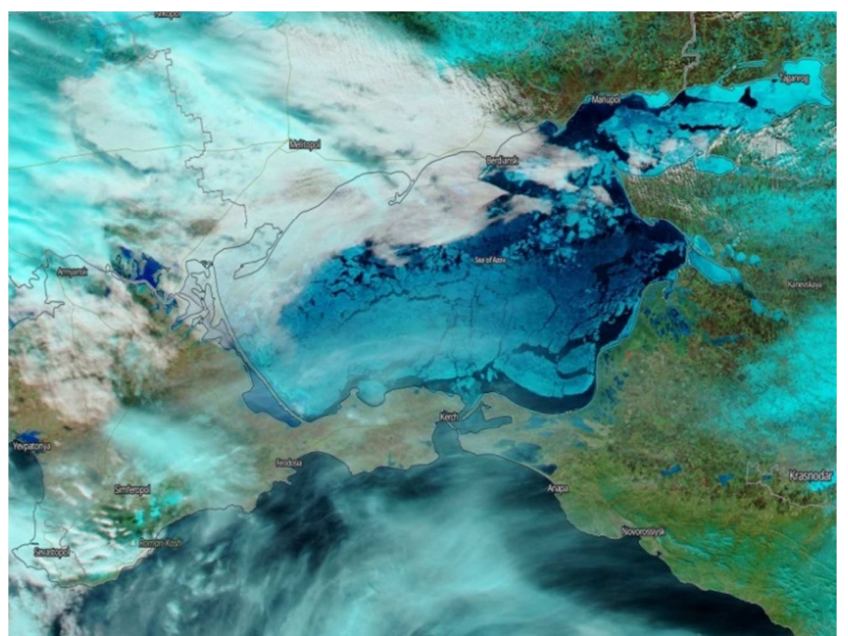

20 Feb 2017

Figure 9. Ice cover formation and drift in the Sea of Azov in February 2017.

It is significant to mention, that the weather conditions for the above dates corresponded to the usual conditions. The average air temperature in Kerch (more precisely at the hydrometeorological station Opasne) in January 2017 was minus $0.4^{\circ} \mathrm{C}$, during February $1-12,2017-$ minus $1.1^{\circ} \mathrm{C}$. Obviously, it is under the lower average air temperature, which is often observed here. The ice situation will be even more stringent.

The daily satellite monitoring of the Kerch Strait in February 2017 made it possible to identify the peculiarities of the formation and drift of the ice cover in Sea of Azov through the Strait. According to the satellite images, it was found that the ice actually don't pass between bridge pillars even when the strong north-east wind blows, including the widest navigable passage.

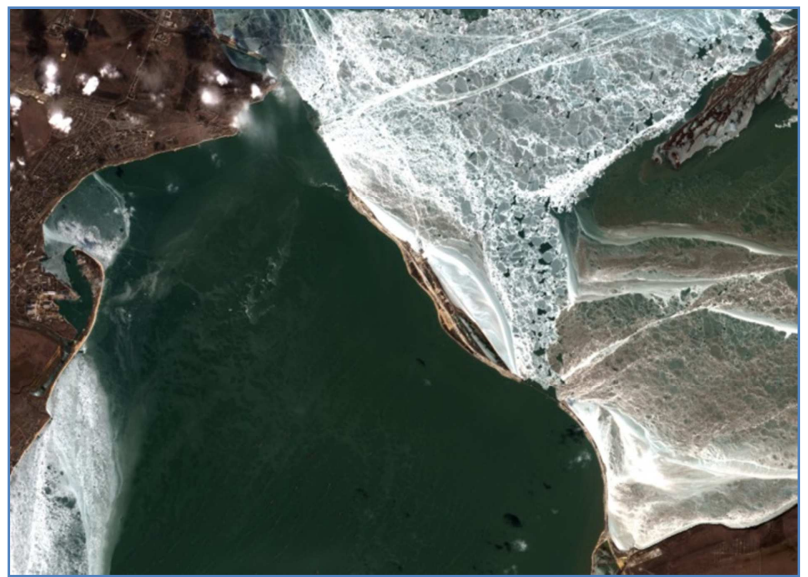

Figure 10. Ice spreading in the Kerch Strait according to the satellite Sentinel $2 a$ dated 13 Feb 2017.

Working bridge constructed across the Kerch Strait caused a stop of the ice drift from the Sea of Azov to Black Sea and caused an ice blocking in the strait. Although the ice is thin $(5-10 \mathrm{~cm})$, there is a large amount of it in Sea of Azov with no way out so the hummock formation began.

The given examples show that the Kerch Strait Bridge 
construction significantly affects the ice situation. The bridge under construction actually plays the role of "dam" that blocks the ice passing through the pillars of the temporary working and main bridge.

Russian specialists also began to write about significant changes within the ice situation influenced by the bridge [6, 7]. The authors of the paper [7] stated that even in the strong north-east wind the ice practically does not pass under the bridge, including its fairway arch. It's worth noting, that it is the case of the most favourable wind for such movement.

We make a point of the fact that the advection of ice in the Kerch Strait from the Sea of Azov is an ordinary situation. The analysis of satellite data collected in this area during the current century and accumulated in the NASA and USGS archives has shown that similar situations emerged, in particular, in January-February 2003, 2006, 2008, 2012, and 2014. At the same time, the ice situation in the Sea of Azov and the ice drift to the Kerch Strait may be much more significant than the situation observed in February 2017 (Figure 11). For example, Figure 12 shows the situation observed in the region on 2-3 February 2014.

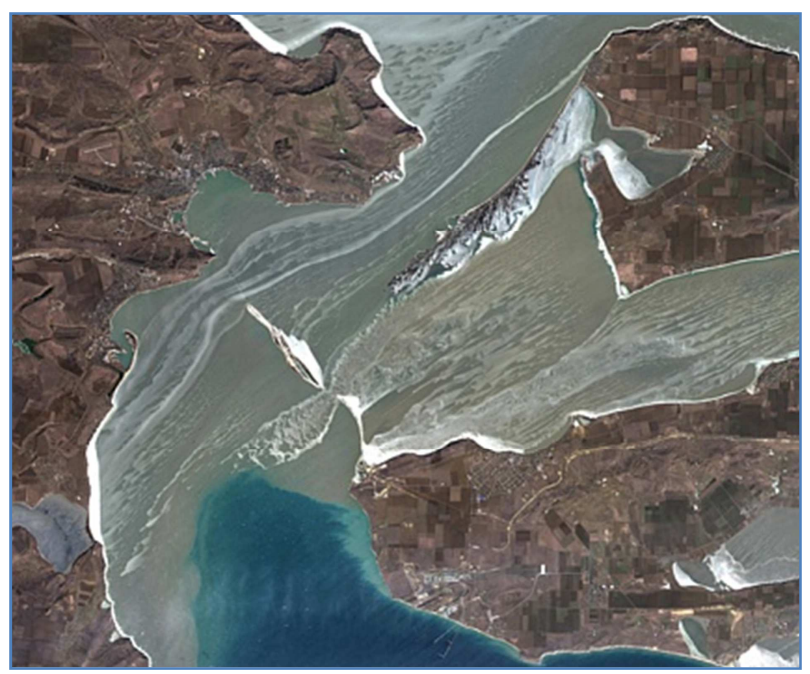

(a)

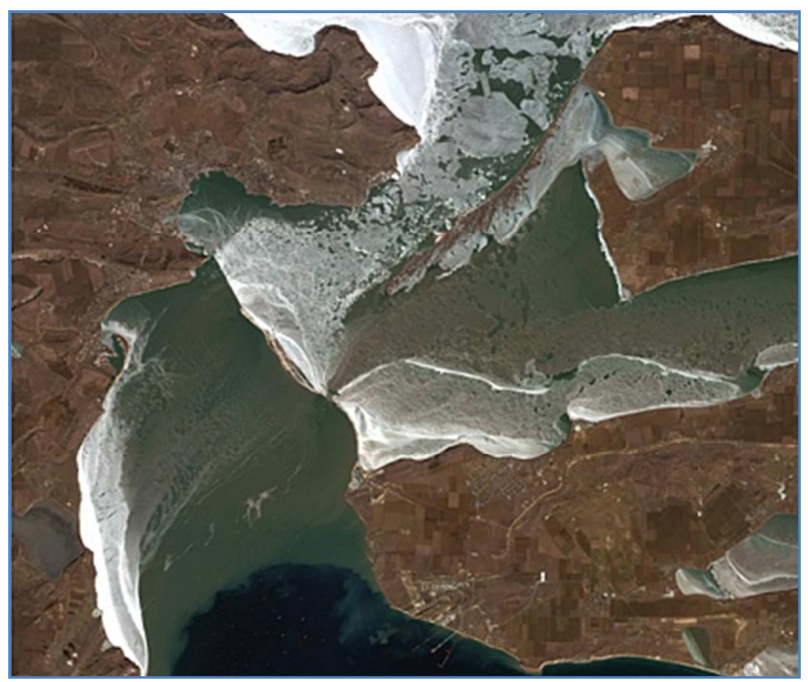

(b)

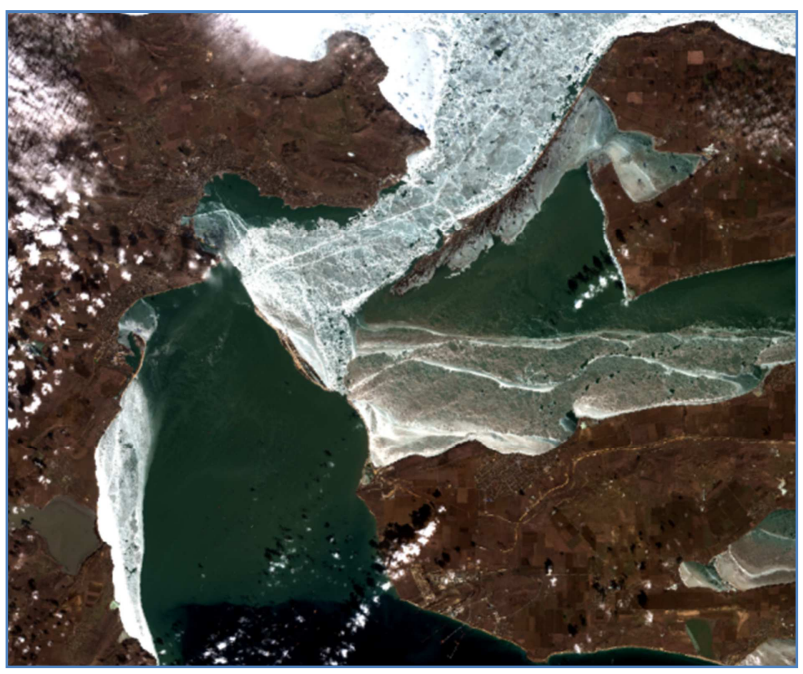

(c)

Figure 11. The Kerch Strait Bridge became a barrier in the way of ice drifting under the influence of the wind from the Sea of Azov to the Black Sea: $a$-Satellite image SPOT 7 (AIRBUS Defence \& Space) dated 09 Feb 2017; $b$ - Satellite image SPOT 7 (AIRBUS Defence \& Space) dated 11 Feb 2017; c-Satellite image Sentinel 2A (ESA) dated 13 Feb 2017.

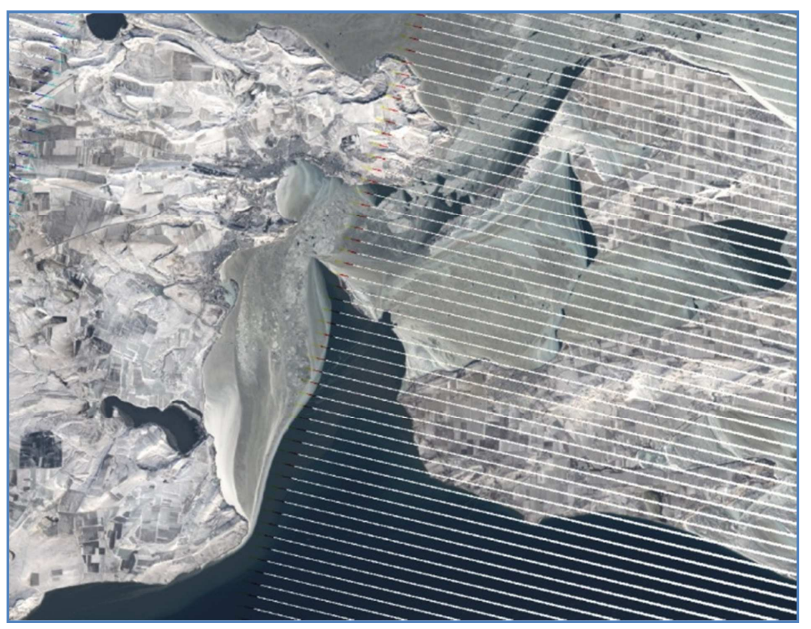

Figure 12. Ice situation in the Azov and Black Seas, ice passing to the Kerch Strait according to satellite image from Landsat 7 dated 03 Feb 2014.

The given data on the ice situation give grounds to assert the fact, that the bridge presence, even at normal winter temperatures, will significantly deteriorate the ice situation in the Kerch Strait. At temperatures below minus $20^{\circ} \mathrm{C}$, which are observed here, the ice in the strait will be very difficult to overcome.

\section{Conclusion}

In general, the Kerch Strait Bridge has a significant impact on the environment, affecting the interests of all Black Sea basin countries. This construction is extremely dangerous for the ecosystems of the Azov and the Black Seas, as well as their coast and is a direct violation of international law [8].

Particularly significant and mostly negative changes will be in the Taman Gulf, most of which belongs to Russia. Reducing water exchange between the Black Sea and the 
Taman Gulf will change the thermal and ice regimes. In summer, the water will get warmer here. In winter, the period of ice formation will lengthen and the thickness of ice will increase. As a result, the shortage of oxygen and subsequent death of fish will be a habitual phenomenon in the Taman Gulf [9].

The consequences of construction and protection of the shores of the Gulf of Taman will be peculiar. When the northern wind is observed (and it usually has the greatest force), very high surge wave will form in the gulf. Accordingly, the destruction of coasts will increase.

The construction of the Kerch Strait Bridge will significantly change the fish living conditions in the Sea of Azov and conditions of its migration to the Black Sea.

A particularly noticeable blow will be observed in the fall, when the majority of fish shoals migrate into the Black Sea, which is warmer in the cold period of the year. It is known that most species of fish that live in the Sea of Azov die at a temperature below $4{ }^{\circ} \mathrm{C}$. The existence of a bridge, which includes a long dam, will significantly deteriorate the conditions of fish migration and will create a real threat to fish life during migration [10].

The negative impact of the bridge affects the water quality and the use of sea for recreation purposes. As a proof of this water blooming in the Sea of Azov was observed to be stronger than usual in the summer of 2017.

In general, the construction of the Kerch Strait Bridge creates real preconditions for gradual transformation of the Sea of Azov into the Black Sea Gulf, and losses caused for natural environment of the Black and the Azov Seas will reach billions of UAH.

\section{References}

[1] Eremeev V. N., Ivanov V. A., Ilyin Yu. P. Oceanographic conditions and environmental problems of the Kerch Strait // Marine ecological journal. - 2003. - T. 2. - No. 3. - P. 27 40 .
[2] Galushchak V. S. and others. Bridge crossing through the Kerch Strait (history, reality, future) // Internet journal Naukovedenie. - 2014. - No. 5 (24).

[3] Dashkevich, L. V., Berdnikov, S. V., Kulygin, V. V. Many-year variations of the average salinity of the Sea of Azov. Water Resources, 2017, 44.5: 749-757.

[4] Fomin, V. V., Lazorenko, D. I., Fomina, I. N. Numerical Modeling of Water Exchange through the Kerch Strait for Various Types of the Atmospheric Impact. Physical Oceanography ISS. 4, 2017, 2: 2.

[5] Rogozhin E. A., Marahanov A. V. Estimation of seismic hazard of low-level regions by the example of the KerchTaman region. - 2017.

[6] Lavrova O. Yu., Mityagina M. I., Kostyanoy A. G. The ice situation in the Kerch Strait in the current century. Retrospective analysis based on satellite data // Modern problems of Earth space remote sensing. - 2017. - T. 14. - No. 2. - pp. 148-166.

[7] Lupyan E. A., and others. Ice situation in the area of the Crimean bridge construction in February 2017 // Modern problems of Earth space remote sensing. - 2017. - T. 14. - No. 1. - p. 247.

[8] Lavrova, O. Y., Mityagina, M. I., Kostianoy, A. G., Strochkov, M. A. Satellite Monitoring of the Black Sea Ecological Risk Areas. Ecologica Montenegrina, 2017, 14: 1-13.

[9] Chepyzhenko, A. A., Chepyzhenko, A. I., Kushnir, V. M. Strait of Kerch water structure derived from the data of contact measurements and satellite imagery. Oceanology, 2015, 55.1: 47-55.

[10] Bryantsev V. A. The potential environmental consequences of the Tuzla dam construction (Kerch Strait) // Marine ecological journal. - 2005. - Vol. 4. - No. 1. - pp. 47-50. 